\title{
HubunganMotivasi Belajar Ekstrinsik Terhadap Hasil Belajar Psikomotorik Pada Mata Pelajaran Agama Kristen Kelas V Di SD Zion Makassar
}

\author{
The relationship between Extrinsic Learning \\ Motivation to Psychomotor Learning Outcomes in \\ Grade V Christian Subjects at Zion Makassar \\ Elementary School
}

\author{
Sifra Sahiu ${ }^{1)}$, Hengki Wijaya ${ }^{* 2)}$ \\ 1) Almuni Sekolah Tinggi Fisafat Jaffray \\ 2) Dosen Sekolah Tinggi Filsafat Jaffray \\ *)Penulis Koresponsdensi: hengkiwijaya@sttjaffray.ac.id
}

\begin{abstract}
Abstrak
Hasil penelitian tentang hubungan motivasi dengan imitasi yang memperoleh nilai skala rating $79,34 \%$ menunjukkan bahwa peserta didik bukan hanya menjadi pendengar saja melainkan melakukan atau meniru setiap pelajaran yang diajarkan yang berhubungan dengan gerakan. Kedua, Hubungan motivasi dengan manipulasi memperoleh nilai skala rating 80,29\% menunjukkan bahwa peserta didik mampu untuk menggunakan konsep dalam melakukan kegiatan seperti meneladani tokoh Alkitab. Ketiga, hubungan motivasi dengan presisi memperoleh nilai skala rating $83,42 \%$ menunjukkan bahwa peserta didik tidak sekadar mengikuti apa yang dikatakan oleh gurunya tetapi mempertimbangkannya yang dapat diterima secara logikanya. Keempat, hubungan motivasi dengan artikulasi memperoleh nilai skala rating $76,75 \%$ menunjukkan bahwa peserta didik masih ragu-ragu dalam merangkai segala sesuatu menjadi suatu hal yang berkesinambungan. Kelima, hubungan motivasi dengan naturalisasi memperoleh nilai skala rating 83,95\% menunjukkan bahwa peserta didik mampu melakukan segala tugas sekolahnya dengan mandiri dan berusaha sendiri. Kesimpulannya adalah keterkaitan motivasi dan hasil belajar psikomotorik merupakan hal yang sangat penting dalam mengembangkan keaktifan anak didik dalam belajar atau melakukan setiap kegiatan sehingga mencapai hasil belajar yang lebih baik.
\end{abstract}

Kata kunci: motivasi, hasil, belajar, psikomotorik, imitasi, manipulasi

The results of this study about the relationship of motivation with imitation that received a score of $79.34 \%$ on the Rating scale, indicate that learners not only are listeners but rather doers or imitaters of any lessons taught related to the kinesthetic movement. Second, the relationship of motivation with manipulation that received a score of $80.29 \%$ on the Rating scale, shows that learners are able to use concepts in doing activities such as emulating a biblical character. Third, the relationship between motivation and precision that received a score of $83.42 \%$ on the Rating scale, demonstrates that learners do not simply follow what the teacher says, but consider it logically acceptable. Fourth, the relationship of motivation with articulation that recieved a score of $76.75 \%$ 
on the Rating scale, suggests that learners are still hesitant in assembling all that they have learned into something that is continuous and consistant. Fifth, the relationship of motivation with naturalization that obtained a score of $83.95 \%$ on the Rating scale, reveals that learners are able to do all their schoolwork independently by their own efforts. The conclusion is that the relationship of motivation and the effects of psychomotor learning is very important in developing activity in students while learning or doing each activity so as to achieve better learning results.

Key words: Motivation, the results, learning, psychomotor , imitation, manipulation

\section{Pendahuluan}

Pada dasarnya motivasi adalah suatu usaha yang disadari untuk menggerakkan, mengarahkan dan menjaga tingkah laku seseorang agar ia terdorong untuk bertindak melakukan sesuatu sehingga mencapai hasil atau tujuan tertentu. ${ }^{1}$ Setiap siswa pasti tidak semuanya memiliki motivasi yang kuat untuk mendorong atau menggerakkan diri mereka dalam belajar, tetapi motivasi sangat diperlukan dalam kegiatan belajar untuk memperoleh hasil belajar yang baik.

Guru sering kali harus mengulang materi yang telah disampaikan agar siswa mengerti, motivasi belajar siswa juga kurang baik, antara lain berbicara dengan teman, acuh tak acuh terhadap apa yang dijelaskan oleh guru, keluar masuk kelas dan hanya sedikit yang benar-benar serius mengikuti apa yang dijelaskan guru. Akibatnya, pemahaman dari suatu materi yang telah disampaikan guru kurang dipahami oleh siswa. ${ }^{2}$

Motivasi saat ini sangat susah dimiliki oleh siswa karena banyak pengaruh dari lingkungan, teman-teman, dan lain-lain. Hal seperti ini sangat sulit dihindari oleh siswa, sulit untuk mencapai hasil belajar yang baik jika hal di luar memengaruhi mereka untuk tidak memiliki keinginan untuk belajar. Khususnya dalam mata pelajaran Agama Kristen yang menyangkut kerohanian setiap siswa Kristiani, karena melihat sekarang ini banyak hasil belajar tidak memuaskan dalam mata pelajaran tersebut.

Jika siswa memiliki motivasi belajar yang tinggi, maka seluruh proses pembelajaran akan diikuti dengan baik mulai dari rasa ingin tahu, intensitas dalam memperhatikan penjelasan pelajaran, membaca materi

\footnotetext{
${ }^{1}$ Ghullam Hamdu dan Lisa Agustina, "Pengaruh Motivasi Belajar Siswa Terhadap Prestasi Belajar IPA di Sekolah Dasar," Jurnal Penelitian Pendidikan 12, No.l (April 2011): 82-83.

${ }^{2}$ Nana Citrawati Lestari, Akhmad Riyadi,"Peningkatan Hasil Belajar Kognitif Siswa Kelas X-2 SMAN 1 Muara Pada Materi IPA Konsep Ekosistem Menggunakan Model Pembelajaran Kooperatif Tipe NHT," Cendekia 9, No. 2 (Oktober 2015): 171.
} 
sampai pada mencari strategi yang paling tepat guna meraih prestasi akademik yang tinggi bagi dirinya. ${ }^{3}$

Dalam tahapannya, hasil belajar psikomotorik dapat dibedakan menjadi lima tahap, yaitu: imitasi, manipulasi, presisi, artikulasi, dan naturalisasi. Imitasi adalah kemampuan melakukan kegiatan-kegiatan sederhana dan sama persis dengan yang dilihat atau diperhatikan sebelumnya. Contohnya, seorang peserta didik dapat mengulang pengucapan sebuah kata setelah gurunya mengucapkan sebelumnya. Manipulasi adalah kemampuan melakukan kegiatan sederhana yang belum pernah dilihat tetapi berdasarkan pada pedoman atau petunjuk saja. Sebagai contoh, seorang peserta didik dapat menulis menginterpretasi gambar dalam sebuah karangan hanya berdasarkan pada petunjuk guru atau teori yang dibacanya. ${ }^{4}$

Tulisan ini akan melihat hubungan motivasi belajar ekstrinsik terhadap hasil belajar psikomotorik pada mata pelajaran agama Kristen pada Sekolah Dasar Zion kelas V. Penulis ingin mmbuktikan bahwa motivasi siswa tidk hanya berpengaruh pada hasil belajar kognitif (pengetahuan), afektif (sikap siswa) tetapi juga hasil belajar psikomotorik.

\section{Motivasi Belajar Siswa}

Dalam membicarakan jenis-jenis motivasi, dalam hal ini akan dilihat dari sudut pandang yaitu, motivasi yang berasal dari dalam diri pribadi seseorang yang disebut motivasi intrinsik dan motivasi yang berasal dari luar diri seseorang yang disebut motivasi ekstrinsik. Jenis motivasi belajar yaitu: ${ }^{5}$

1. Motivasi intrinsik. Wasty Soemanto mengutip pernyataan Winkel, motivasi timbul dari dalam diri seseorang tanpa bantuan orang lain. ${ }^{6}$ Sedangkan menurut Syaiful Djamarah motivasi intrinsik adalah motifmotif yang menjadi aktif atau berfungsinya tidak perlu dirangsang. ${ }^{7}$ Berdasarkan pendapat di atas dapat disimpulkan bahwa motivasi ekstrinsik adalah motivasi yang timbul dari dalam diri seseorang untuk

\footnotetext{
${ }^{3}$ Izuddin Syarif, "Pengaruh Model Blended Learning Terhadap Motivasi dan

Prestasi Belajar Siswa SMK", Jurnal Pendidikan Vokasi 2,No. 2 (Juni 2012):236.

${ }^{4}$ Andi Nurwati, "Penilaian Ranah Psikomotorik Siswa Dalam Pelajaran Bahasa," Edukasia: Jurnal Penelitian Pendidikan Islam 9, No. 2 (Agustus 2014):392.

${ }^{5}$ Rohmalina Wahab, Psikologi Belajar (Jakarta: RajaGrafindo Persada, 2016), 129.

${ }^{6}$ Rohmalina Wahab, Psikologi Belajar, 129; Wasty Soemanto, Psikologi

Pendidikan:Landasan Kerja Pemimpin Pendidikan (Jakarta: Rineka Cipta, 2006). Wasty

Soemanto mengutip pandangan Winkel dari buku Rohmalia Wahab.

${ }^{7}$ Rohmalina Wahab, Psikologi Belajar, 129; Syaiful Bahri Djamarah, Psikologi Belajar (Jakarta: Rineka Cipta, 2008).
} 
bertindak melakukan segala sesuatu tanpa rangsangan dari luar. Motivasi itu muncul dari kesadaran diri sendiri dengan tujuan secara esensial, bukan sekadar simbol dan seremonial. ${ }^{8}$

2. Motivasi ekstrinsik. Menurut Syaiful Bahri Djamarah, motivasi ekstrinsik adalah motif-motif yang aktif karena adanya rangsangan dari luar. ${ }^{9}$ Motivasi ekstrinsik adalah motivasi yang timbul karena adanya rangsangan dari luar. ${ }^{10}$

Dalam interaksi edukatif tidak semua anak didik termotivasi untuk bidang studi tertentu. Motivasi anak didik untuk menerima pelajaran tertentu berbeda-beda, ada anak didik yang memiliki motivasi yang tinggi, ada yang sedang, dan ada juga yang sedikit sekali motivasi. Jika terdapat anak didik yang kurang termotivasi untuk belajar, peranan motivasi ekstrinsik yang bersumber dari luar diri anak didik sangat diperlukan. Motivasi ekstrinsik ini diberikan bisa dalam bentuk ganjaran, pujian, hadiah, dan sebagainya. ${ }^{l l}$

\section{Sifat-Sifat Motivasi}

Berikut ini merupakan sifat-sifat motivasi: ${ }^{12}$

a. Kekuatan suatu motif, suatu motif yang kuat tidak tentu kalau ini berlangsung lama, sedangkan suatu motif yang lama tidak tentu kalau kuat. Sebagai contoh orang sangat lapar kalau sudah diberi makan, maka motif ini akan lekas hilang.

b. Motif yang berubah-ubah, motif kadang-kadang menjadi tujuan tetapi kalau sudah tercapai lalu berubah menjadi jalan ke tujuan yang lain. Contoh motif menjadi mahasiswa adalah untuk mencapai gelar sarjana.

c. Motivasi asli dan motivasi yang di dapat, motivasi yang asli ialah motifmotif yang ditentukan secara struktural dan sosial, dana alamiah dalam arti bahwa motif itu umum pada manusia. Dengan lain perkataan ialah dorongan-dorongan yang kita jumpai setiap hari motif-motif yang alamiah ini dapat menjadi dasar dari motivasi yang diperlukan dalam belajar.

\section{Sifat Dasar Penguatan Motivasi}

Sifat dasar penguatan terbagi dua, yaitu: ${ }^{13}$

${ }^{8}$ Wahab., 90.

${ }^{9}$ Wahab, 129; Syaiful Bahri Djamarah, Psikologi Belajar (Jakarta: Rineka Cipta, 2008).

${ }^{10}$ Wahab, 129.

${ }^{11}$ Syaiful Bahri Djamarah, Guru dan Anak Didik Dalam Interaksi Edukatif (Jakarta: Rineka Cipta, 2000), 64. 73.

${ }^{12}$ Mustaqim, Abdul Wahid, Psikologi Pendidikan (Jakarta: Rineka Cipta, 2013), 72

${ }^{13}$ Kelvin Seifert, Manajemen Pembelajaran dan Instruksi Pendidikan (Jogjakarta:

IRCiSoD, 2007), 33-34. 
1. Penguatan motivasi positif versus penguatan motivasi negatif

Dalam Penguatan motivasi positif, beberapa bentuk penghargaan, objek atau peristiwa yang diinginkan, diberikan sebagai konsekuensi dari operant yang dilakukan. Dalam penelitian yang dilakukan Skinner terhadap objek orang, penguat motivasi seringkali berbentuk penghargaan non-fisik: sebuah pujian bagi siswa dalam kelas atau sebuah komisi bagi karyawan pemasaran dalam bisnis-bisnis tertentu.

Dalam penguatan motivasi negatif, beberapa Jika seorang anak bisa menghindari omelan gurunya dengan menyelesaikan tugas tepat pada waktunya, maka itu artinya dia mendapatkan penguatan motivasi yang negatif. Dalam masing-masing kasus, tingkat probabilitas sebuah perilaku meningkat karena konsekuensinya: itulah sebabnya mengapa konsekuensi tersebut dianggap sebagai "penguat motivasi". Oleh karena itu, penguatan motivasi negatif memiliki fungsi yang sama dengan penguatan motivasi positif: perbedaannya, penguat motivasi negatif bekerja dengan menghindari hal-hal yang tidak diinginkan, sementara penguat motivasi positif bekerja dengan mengharapkan hal-hal yang tidak diinginkan. ${ }^{14}$

2. Penguatan motivasi versus hukuman

Apakah seorang guru bekerja di sekolah atau di tempat-tempat lainnya, ia harus mampu membedakan penguat motivasi, baik yang positif maupun yang negatif, dengan komponen penting ketiga dari konsekuensi pendidikan, hukuman. Tidak seperti penguat motivasi, hukuman secara aktif akan menekan perilaku. Di samping itu, hukuman terkadang bisa menghalangi perilaku positif dari obyek yang mendapatkan hukuman, seperti seorang anak yang mendapatkan kritik keras karena telah memberikan jawaban yang salah sangat mungkin berhenti memberi jawaban sama sekali. ${ }^{15}$

\section{Indikator Motivasi Dalam Belajar}

Dalam proses interaksi belajar mengajar, baik motivasi intrinsik maupun motivasi ekstrinsik, diperlukan untuk mendorong anak didik supaya tekun belajar. Motivasi ekstrinsik sangat diperlukan bila ada di antara anak didik yang kurang berminat mengikuti pelajaran dalam jangka waktu tertentu. Peranan motivasi ekstrinsik cukup besar untuk membimbing anak didik dalam belajar. Ada beberapa indikator motivasi

${ }^{14}$ Kelvin Seifert, Manajemen Pembelajaran dan Instruksi Pendidikan (Jogjakarta: IRCiSoD, 2007), 33-34.

${ }^{15}$ Seifert, 34-35. 
yang dapat dimanfaatkan dalam rangka mengarahkan belajar anak didik di kelas, sebagai berikut: ${ }^{16}$

\section{Angka}

Angka dimaksud adalah sebagai simbol atau nilai dari hasil aktivitas belajar anak didik. Angka merupakan alat motivasi yang cukup memberikan rangsangan kepada anak didik untuk mempertahankan atau bahkan lebih meningkatkan prestasi belajar mereka di masa mendatang.

Siswa yang rajin belajar akan mempertahankan prestasinya, sehingga dalam ulangan atau tes harian yang diberikan mereka termotivasi untuk belajar bersaing mendapat nilai yang tinggi. Tetapi, kebanyakan siswa jika diberikan ulangan, masih ada yang menyontek sehingga peran guru dibutuhkan dalam memberikan motivasi kepada peserta didik. Ketika mereka bersaing tanpa menyontek itu akan menguji mental untuk berpikir dan berusaha sendiri dan disitulah motivasi untuk memperjuangkan meraih prestasi yang terbaik.

\section{Hadiah}

Hadiah adalah memberikan sesuatu kepada orang lain sebagai penghargaan sebagai wujud apresiasi kepada seseorang. Dalam dunia pendidikan, hadiah bisa dijadikan sebagai alat motivasi. Hadiah dapat diberikan kepada anak didik yang berprestasi tinggi, rangking satu, dua atau tiga dari anak didik lainnya.

Pemberian hadiah kepada yang berprestasi sangat bagus untuk memberikan motivasi kepada teman yang lainnya, sehingga anak didik berusaha belajar agar mendapatkan juara serta mendapat hadiah dari hasil kerja keras belajarnya. Kebanyakan sekolah sudah mempraktikkan hal ini kepada siswa-siswanya yang berprestasi dalam belajar. Di samping itu, guru tetaplah memberikan motivasi kepada anak didiknya yang masih gagal atau sementara berjuang supaya mereka tetap memiliki semangat.

\section{Kompetisi}

Kompetisi adalah persaingan dapat digunakan sebagai alat motivasi untuk mendorong anak didik supaya mereka bergairah belajar. Persaingan, baik dalam bentuk individu maupun kelompok diperlukan dalam pendidikan.

Di sekolah dalam kegiatan belajar, biasanya diadakan diskusi kelompok untuk bersaing dengan kelompok lainnya atau kompetisi perorangan, sehingga masing-masing belajar dengan tekun. Biasanya dalam sekolah tertentu, mengadakan kompetisi dalam satu sekolah dulu sehingga yang menjadi juara akan diutus mengikuti kompetisi beda

${ }^{16}$ Djamarah, 158-16l. 
sekolah. Semakin tinggi persaingan antar orang, akan semakin kuat juga motivasi siswa untuk giat belajar dan mencapai tujuan yang hendak dicapai. Oleh sebab itu, anak didik tidak bisa sendiri saja untuk memotivasi dirinya tetapi ada juga dukungan orang tua dan guru dalam menyarankan siswanya atau anaknya dalam meningkatkan belajarnya di sekolah maupun di rumah.

\section{Hakikat Psikomotorik}

Psikomotorik berkaitan dengan tindakan dan keterampilan, seperti lari, melompat, melukis, dan sebagainya. Dalam dunia pendidikan, psikomotorik terkandung dalam mata pelajaran praktik. Psikomotorik memiliki korelasi dengan hasil belajar yang dicapai melalui manipulasi otot dan fisik. ${ }^{17}$

Psikomotorik tidak bisa dipisahkan dari kognitif dan afektif. Sebaliknya, psikomotorik juga tidak bisa berdiri sendiri. Proses belajar dimulai dari tahap kognitif (berpikir), kemudian afektif (bersikap), baru psikomotorik (berbuat). Meskipun kognitif dan afektif kini mulai dipisahkan, keduanya masih tetap mengandung psikomotorik. Afektif yang bergantung pada psikomotorik juga bisa ditemukan dalam pelajaran Agama misalnya praktik tata cara beribadah dan berdoa. ${ }^{18}$

\section{Fungsi Psikomotorik}

Fungsi psikomotorik dalam telaah Baharuddin dinamai fungsi amalan. Menurutnya, fungsi psikomotorik cenderung pada tingkah laku mekanistik yang dilaksanakan tanpa melalui proses penghayatan dan kesadaran, sedangkan fungsi amalan dapat mencakup tingkah laku humanistik. Fungsi amalan dalam perumusannya adalah bertemunya daya batin yang mengarahkan kehidupan manusia dengan daya lahir yang melingkupi dan mendukungnya dalam gerakan atau perbuatan. Dalam dunia pendidikan mikro, bentuk motivasi yang lazim dilakukan para pendidik mencakup kegiatan, seperti memberi angka yang merupakan simbol dari nilai kegiatan belajar. Angka yang baik dan tinggi biasanya memperkuat motivasi peserta didik dalam belajar. Bentuk lainnya adalah menghidupkan kompetisi yang sehat di antara para peserta didik. Bahkan,

\footnotetext{
${ }^{17}$ Toto Haryadi, Aripin, "Melatih Kecerdasan Kognitif, Afektif, dan Psikomotorik Anak Sekolah Dasar Melalui Perancangan Game Simulasi "Warungku," Jurnal Desain Komunikasi Visual \& Multimedia 1, No. 2 Tahun 2015:43-44.

${ }^{18}$ Toto Haryadi, Aripin, "Melatih Kecerdasan Kognitif, Afektif, dan Psikomotorik Anak Sekolah Dasar Melalui Perancangan Game Simulasi "Warungku," Jurnal Desain Komunikasi Visual \& Multimedia 1, No. 2 Tahun 2015:43-44.
} 
dalam banyak bidang kehidupan manusia semangat berkompetisi adalah ajang memperkuat motivasi. ${ }^{19}$

\section{Perkembangan Psikomotorik Siswa}

Dalam psikologi, kata motor digunakan sebagai istilah yang menunjuk pada hal, keadaan dan kegiatan yang melibatkan otot-otot dan gerakangerakannya. Secara singkat, motor dapat pula dipahami sebagai segala keadaan yang meningkatkan atau menghasilkan stimulasi atau rangsangan terhadap kegiatan organ-organ fisik. Belajar keterampilan fisik (motor learning) dianggap telah terjadi dalam diri seseorang apabila ia telah memperoleh kemampuan dan keterampilan yang melibatkan penggunaan tangan (seperti menggambar) dan tungkai (seperti berlari) secara baik dan benar. Untuk belajar memperoleh kemampuan keterampilan jasmani ini, ia tidak hanya cukup dengan latihan dan praktik, tetapi juga memerlukan kegiatan perceptual learning (belajar berdasarkan pengamatan) atau kegiatan sensory-motor learning (belajar keterampilan inderawi-jasmani). Dalam kenyataan sehari-hari, cukup banyak keterampilan inderawi-jasmani yang rumit dan karenanya memerlukan upaya manipulasi (penggunaan secara cepat), koordinasi, dan organisasi rangkaian gerakan secara tepat. Motor skills (kecakapankecakapan jasmani) perlu dipelajari melalui aktivitas latihan langsung yang disertai dengan pengajaran teori-teori pengetahuan yang berhubungan dengan motor skills itu sendiri. Sementara itu, aktivitas latihan perlu dilaksanakan dalam bentuk praktik yang berulang-ulang oleh siswa, termasuk praktik contoh gerakan-gerakan yang salah dan tidak dibutuhkan, sehingga siswa dapat memahami bagian mana yang keliru, kemudian upaya perbaikan segera dilakukan. ${ }^{20}$

Belajar keterampilan fisik (motor learning) di anggap telah terjadi dalam diri seseorang apabila ia telah memperoleh kemampuan dari keterampilan yang melibatkan penggunaan lengan (seperti menggambar) dan tungkai (seperti berlari) secara baik dan benar. Untuk belajar memperoleh kemampuan keterampilan jasmani ini, ia tidak hanya cukup dengan latihan dan praktik, tetapi juga memerlukan kegiatan perceptual learning (belajar berdasarkan pengamatan) atau kegiatan sensory-motor learning (belajar keterampilan inderawi-jasmani). Dalam kenyataan seharihari cukup banyak keterampilan inderawi-jasmani yang rumit dan karenanya memerlukan upaya manipulasi (penggunaan secara cermat), koordinasi, dan organisasi rangkaian gerakan secara tepat. Motor skills

\footnotetext{
${ }^{19}$ Hasan Basri, Kapita Selekta Pendidikan (Bandung: Pustaka Setia, 2012), 289.

${ }^{20}$ Muhibbin Syah, Psikologi Pendidikan dengan Pendekatan Baru (Bandung: Remaja Rosdakarya, 2008), 13-17.
} 
(kecakapan-kecakapan jasmani) perlu dipelajari melalui aktivitas latihan langsung yang disertai dengan pengajaran teori-teori pengetahuan yang berhubungan dengan motor skills itu sendiri. ${ }^{21}$

Gerakan-gerakan motorik siswa akan terus meningkat keanekaragaman, keseimbangan, dan kekuatannya, ketika ia menduduki bangku SLTP dan SLTA. Namun, peningkatan kualitas bawaan siswa ini justru membawa konsekuensi sendiri, yakni perlunya pengadaan guru yang lebih piawai dan terampil. ${ }^{22}$

Sementara itu, aktivitas latihan perlu dilaksanakan dalam bentuk praktik yang berulang-ulang oleh siswa, termasuk praktik contoh gerakan-gerakan yang salah dan tidak dibutuhkan, sehingga siswa dapat memahami bagian mana yang keliru, kemudian upaya perbaikan segera dilakukan. ${ }^{23}$

\section{Dimensi Psikomotorik}

Dimensi (ranah) psikomotorik meliputi aktivitas motorik yang penting dalam pengembangan kemampuan siswa dalam memanipulasi benda-benda, dan secara umum mengembangkan keterampilan motorik siswa. Psikomotorik berhubungan dengan gerakan sengaja yang dikendalikan oleh aktivitas otak. Dimensi psikomotorik umumnya berupa keterampilan yang memerlukan koordinasi otak dengan beberapa otot. Dave mengembangkan teori Bloom ini dengan mengklasifasikan domain psikomotorik ke dalam lima kategori, mulai dari tingkat yang paling rendah sampai tingkat yang paling tinggi, kelima kategori tersebut adalah: ${ }^{24}$

\section{Imitation (Peniruan)}

Keterampilan untuk menentukan suatu gerakan yang telah dilatih sebelumnya. Latihan ini bisa dilakukan dengan cara mendengarkan atau memperlihatkan. Contohnya, seorang siswa mengamati demonstrasi guru dan kemudian siswa tersebut meniru proses atau aktivitas guru.

Berbagai macam cara pun dilakukan untuk mewujudkan hal tersebut. Salah satu yang harus juga dilakukan oleh guru kepada anak didiknya adalah mengenal lebih mendalam bukan sekadar murid dengan guru, melainkan menjadikannya seperti seorang sahabat kepada anak tersebut.

${ }^{21}$ Syah, 13-17.

${ }^{22}$ Muhibbin Syah, Psikologi Pendidikan dengan Pendekatan Baru (Bandung: Remaja Rosdakarya, 2008), 62.

${ }^{23}$ Ibid., 13-17.

${ }^{24}$ Suryadi, Psikologi Belajar PAUD (Yogyakarta: Pustaka Insan Madani, 2010), 73; Dave R. H., Psychomotor Levels in Developing and Writing Behavorial Objectives (Arizona: Educational Innovators Press, 1970). 
Seorang sahabat yang menaruh kasih setiap waktu dan menjadi seorang saudara dalam kesukaran (Ams. 17:17). Segala sesuatu tindakan yang didasarkan dengan kasih akan membuat sesuatu yang biasa menjadi hal yang luar biasa.

Persahabatan antara seorang guru dan anak didik adalah suatu hal yang jarang ditemukan dalam dunia pendidikan. Ada beberapa guru yang dalam mengajar terus-menerus menekankan hal yang harus dilakukan, jika tidak dilakukan maka akan mendapat sanksi. Dari hal ini guru mengajar dengan otoriter yang akan membuat anak tertekan bahkan jika mengingat nama guru tersebut anak merasa sangat takut untuk bertemu dengan guru tersebut.

Pada tahap ini, anak akan menyelesaikan masalahnya dengan keterampilan yang telah dilihat dan diperdengarkan kepadanya dengan beberapa latihan antara pikiran dan otot. Pikiran dan otot pada anak menghasilkan sesuatu yang besar bahkan tidak dapat diduga oleh orang tua khususnya pada guru yang selama ini memperdengarkan sesuatu yang positif kepada anak didik tersebut.

\section{Manipulation (Penggunaan Konsep)}

Kemampuan untuk menggunakan konsep dalam melakukan kegiatan. Kemampuan juga sering disebut sebagai kemampuan manipulasi. Sebab, tahap ini perkembangan anak selalu mengikuti arahan, penampilan, gerakan-gerakan, dan menetapkan suatu keterampilan gerak tertentu berdasarkan latihan. Kata kerja yang digunakan misalnya: mengikuti (petunjuk), melengkapi, menampilkan, memainkan, menghasilkan (sesuai petunjuk), dan lain-lain.

Penggunaan konsep membuat anak belajar sesuatu hal yang baru. Untuk belajar sesuatu yang baru, seorang anak membutuhkan disiplin baik dari guru maupun dari orang tua.

\section{Presition (Ketelitian)}

Kemampuan yang berkaitan dengan gerak yang mengindikasikan tingkat kedetailan tertentu. Kemampuan fisik-motorik ini sebenarnya hampir sama dengan gerak fisik-motorik pada tahap manipulasi. Hanya saja, pada tahap ini telah mencapai tingkat kontrol yang lebih tinggi, sehingga kesalahannya dapat dieliminasi.

Dengan adanya ketelitian yang dimiliki oleh anak yang dihasilkan dari kemampuan gerak-motorik akan menghasilkan anak yang bertindak dengan leluasa kepada tingkat detail yang akan dicapainya. Dalam tahap ini, seorang anak tidak sekadar mengikuti apa yang dikatakan oleh orang lain, tetapi perkataan orang lain dalam hal ini guru akan dipertimbangkan dengan baik untuk menghasilkan suatu hal yang masuk akal yang dapat diterima secara logikanya. 
Ketelitian yang dimiliki anak didik di tahap ini diperoleh dengan latihan-latihan yang ditekuni untuk mengikuti arahan, gerakan-gerakan dan menetapkan suatu gerakan tertentu. Segala sesuatu diterima ketika adanya latihan secara berulang-ulang. Proses ini membutuhkan waktu yang cukup lama dan membutuhkan pendampingan selama melaksanakan latihan untuk mencapai tingkat kontrol yang lebih tinggi.

\section{Articulation (Perangkaian)}

Kemampuan untuk melakukan serangkaian gerakan secara kombinatif dan berkesinambungan. Kemampuan ini membutuhkan koordinasi antar organ tubuh, saraf, dan mata secara cermat. Kemampuan ini dapat ditingkatkan pada mengurutkan serangkaian gerak secara berkesinambungan, konsisten, ajeg dan luwes.

Organ tubuh, saraf dan mata mempunyai peranan yang sangat penting dalam perangkaian. Siswa mempunyai perangkaian yang matang jika koordinasi dari organ tubuh, saraf dan mata berjalan berkesinambungan. Dalam merangkai sesuatu hal siswa dapat juga mengaitkan satu peristiwa dan hal-hal yang terjadi dengan cermat. Kecermatan dari siswa tidak didapat karena tindakan orang lain, melainkan pada siswa itu sendiri. Orang lain hanya sekadar memberikan masukan dan dorongan, tetapi yang merangkai segala sesuatu menjadi sesuatu hal yang utuh merupakan hal yang harus dilakukan oleh anak tersebut.

Perangkaian haruslah dilandasi dengan pengajaran yang sesuai dengan etika dan moral. Perkembangan moral berkaitan dengan kognitif anak. Anak akan menghasilkan sesuatu entah itu baik atau buruk, jika dari awal ia sudah ditanamkan hal tersebut dari masa kecilnya. Anak akan menghasilkan hal yang buruk jika ajaran yang diperdengarkan oleh guru atau orang tua kepada anak adalah hal-hal yang sembrono.

Pengajaran yang diperdengarkan oleh anak akan menjadi suatu kesimpulan yang akan diambil oleh anak pada akhirnya. Oleh karena itu, mulai dari masa kecil haruslah diperdengarkan kepada anak dengan halhal yang positif sehingga menghasilkan suatu rangkaian ilmu pengetahuan yang positif yang dapat dikembangkan dari masa anak-anak hingga ia dewasa kelak.

\section{Naturalization (Kewajaran/Kealamiahan)}

Kemampuan untuk melakukan gerak secara wajar atau luwes. Untuk dapat melakukan gerak fisik-motorik pada tahap ini diperlukan koordinasi tingkat tinggi antara saraf, pikiran, mata, tangan, dan anggota badan yang lain. Oleh karena itu, gerak fisik-motorik pada tahap ini seringkali menguras tenaga dan pikiran. 
Kategori ini relatif sulit dicapai dalam pembelajaran tingkat SD. Kata kerja yang dapat digunakan untuk kategori manipulasi misalnya mendesain, menentukan, mengatur, menemukan, mengelola proyek, dan lain-lain.

Kemampuan ini sangat sulit untuk diterapkan oleh anak SD karena untuk mewujudkan hal ini tubuh dan otak harus berjalan bersamaan untuk mendesain, menentukan, menemukan, mengola proyek. Ada banyak kesulitan yang akan dijumpai dalam tahap ini, tetapi kembali kepada komitmen guru bahwa apapun tingkat kesulitan yang dihadapi tidak menjadikan tingkat kesulitan itu sebagai alasan untuk mundur, tetapi dengan tantangan yang dihadapi membuat seorang guru terus berjuang untuk memberikan dorongan atau motivasi kepada anak untuk mengembangkan tingkat potensi yang dimiliki oleh anak.

Berhasil atau tidak berhasilnya tahap ini bukan suatu masalah yang penting, yang terpenting di sini adalah bagaimana daya juang anak didik untuk mengembangkan kemampuan ini. Mencoba sesuatu yang baru tidak akan membuat seseorang akan mencapai keberhasilan. Keberhasilan diperoleh oleh anak ketika anak terus-menerus belajar dari kegagalan yang terimanya dan terus mengolah saraf, pikiran, mata, tangan dan anggota badan yang lain untuk terus menggali potensi yang ada dalam diri anak didik.

\section{Hasil Pembelajaran Psikomotorik}

Menurut Suharsimi, "Siswa yang sudah dimasukkan ke dalam alat pemrosesan, yaitu transformasi, dan sudah menjadi bahan jadi, dikenal dengan istilah hasil atau keluaran (output)". ${ }^{25}$ Secara mudah didapatkan bahwa hasil pembelajaran adalah siswa yang telah menjadi bahan jadi setelah melalui tahapan tranformasi atau pemrosesan, yaitu kegiatan belajar mengajar. Kualitas proses pembelajaran sangat penting untuk memperoleh hasil yang baik. Hasil belajar adalah perubahan perilaku akibat belajar. ${ }^{26}$

Perubahan perilaku disebabkan karena mencapai penguasaan atas sejumlah bahan yang diberikan dalam proses belajar mengajar. Perubahan perilaku siswa setelah belajar merupakan hasil belajar. Siswa setelah mengikuti proses pembelajaran akan mencapai penguasaan materi pembelajaran yang diberikan, penguasaan materi menyebabkan perubahan perilaku siswa. Perubahan perilaku harus selalu sesuai dengan

${ }^{25}$ Suharsimi Arikunto, Dasar-Dasar Evaluasi Pendidikan (Jakarta: Bumi Aksara, 2009), 295.

${ }^{26}$ Ulfa Fahmanisa, Tips Memahami Peserta Didik (Bandung: Boenz Enterpise), 66-68; Suharsimi Arikunto, Dasar-Dasar Evaluasi Pendidikan (Jakarta: Bumi Aksara, 2009), 295. 
tujuan pembelajaran yang di tetapkan. Perubahan perilaku siswa harus mencakup perubahan dalam aspek kognitif, afektif, dan psikomotorik. Ketiga tipe tersebut merupakan satu kesatuan yang utuh, sehingga tidak bisa dipisah-pisahkan. ${ }^{27}$

Tipe hasil belajar yang ketiga berkaitan dengan aspek psikomotor yang meliputi skill (keterampilan) dan kemampuan. Hasil pembelajaran dapat diukur dengan mengkaji beberapa persoalan berikut. ${ }^{28}$

a. Apakah hasil belajar yang diperoleh siswa dalam bentuk perubahan tingkah laku secara menyeluruh?

b. Apakah hasil belajar yang dicapai siswa mempunyai daya guna dan dapat diaplikasikan dalam kehidupan siswa?

c. Apakah hasil belajar yang dicapai siswa tahan lama diingat dan cukup mempengaruhi perilakunya?

d. Apakah guru yakin bahwa perubahan siswa merupakan akibat dari proses pembelajaran ${ }^{29}$

Cara yang dipandang tepat untuk mengevaluasi keberhasilan belajar yang berdimensi ranak psikomotor (ranah karsa) adalah observasi. Observasi dalam hal ini, dapat diartikan sebagai sejenis tes mengenai peristiwa, tingkah laku, atau fenomena lain, dengan pengamatan langsung. Namun, observasi harus dibedakan dari eksperimen, karena eksperimen pada umumnya dipandang sebagai salah satu cara observasi. ${ }^{30}$

\section{Hasil Pembahasan}

\section{Subjek Penelitian}

Subjek penelitian adalah siswa kelas V SD Zion yang adalah responden dalam penelitian ini. Jumlah responden adalah 83 siswa.

Tabel 1. Profil Subjek Penelitian

\begin{tabular}{|c|c|c|c|c|}
\hline No & Kelas & Laki-Laki & Perempuan & Jumlah \\
\hline 1 & V Celcius & 15 & 12 & 27 \\
\hline 2 & V Kelvin & 16 & 12 & 28 \\
\hline 3 & V Fahrenheit & 15 & 13 & 28 \\
\hline \multicolumn{4}{|c|}{ Total } & 83 \\
\hline
\end{tabular}

${ }^{27}$ Fahmanisa, 66-68.

${ }^{28}$ Fahmanisa, 69.

${ }^{29}$ Nana Sudjana, Penilaian Hasil Proses Belajar Mengajar (Bandung: Remaja Rosdakarya, 2010), 37-39.

30 Syah, 156. 


\section{Analisis Interpretasi Data dan Pembahasannya}

Analisis interpretasi data berdasarkan penilaian responden dalam mengisi angket pada 5 skala penilaian yaitu sangat setuju, setuju, raguragu, tidak setuju dan sangat tidak setuju. Penilaian ini untuk mengetahui pemahaman siswa tentang hubungan motivasi belajar ekstrinsik dengan menggunakan pengukuran skala rating untuk setiap pertanyaan yang dijawab oleh responden selanjutnya penulis akan membahasnya melalui interpretasi data dan pembahasan tentang hubungan kedua variabel.

Variabel motivasi ekstrinsik siswa yang terdiri atas angka/nilai, hadiah dan kompetisi adalah variabel yang konstan artinya siswa termotivasi untuk mengikuti arahan guru, namun pengaruh terhadap hasil belajar psikomotoriknya akan berbeda-beda. Adanya hubungan motivasi ekstrinsik siswa terhadap hasil belajar psikomotorik ditentukan oleh jawaban responden sebagai respons atas pertanyaan yang diajukan.

Dalam penelitian ini hasil belajar psikomotorik juga diukur dengan memberikan tugas kepada siswa untuk praktik psikomotoriknya dalam mata pelajaran agama Kristen dalam proses belajar di kelas. Selanjutnya penulis menghubungkan hasil interpretasi data dan hasil belajar psikomotorik siswa.

Tabel 2. Hubungan Motivasi Ekstrinsik Terhadap Hasil Belajar Psikomotorik

\begin{tabular}{|l|c|c|}
\hline \multicolumn{1}{|c|}{ Hubungan } & $\begin{array}{c}\text { Persentasi } \\
\text { Skala Rating }\end{array}$ & Kategori \\
\hline Motivasi Ekstrinsik Terhadap Imitasi & $79,34 \%$ & Setuju \\
\hline Motivasi Ekstrinsik Terhadap Manipulasi & $80,29 \%$ & Sangat Setuju \\
\hline Motivasi Ekstrinsik Terhadap Presisi & $83,42 \%$ & Sangat Setuju \\
\hline Motivasi Ekstrinsik Terhadap Artikulasi & $83,95 \%$ & Sangat setuju \\
\hline Motivasi Ekstrinsik Terhadap Naturalisasi & $76,75 \%$ & Setuju \\
\hline
\end{tabular}

Hubungan Motivasi Ekstrinsik Terhadap Imitasi

Penilaian responden terhadap pertanyaan yang mengungkapkan hubungan motivasi ekstrinsik terhadap imitasi dipengaruhi oleh pemahaman siswa yang terbentuk untuk melakukan imitasi untuk hal-hal yang mengakibatkan hukuman menunjukkan nilai yang tinggi dibandingkan pemahaman yang dimotivasi oleh hadiah, nilai, dan kompetisi. Siswa tidak terbiasa untuk melakukan imitasi kepada teman sebayanya, justru ada kecenderungan untuk menaati aturan. Oleh karena itu motivasi siswa cenderung digerakkan oleh hal-hal yang berhubungan dengan disiplin, aturan, dan kebiasaan yang terbentuk dari keluarga seperti rajin ke sekolah, membuat tugas bersama orang tua, dan sikap hormat kepada orang tua. 
Hubungan motivasi terhadap imitasi memperoleh nilai skala rating 79,34\%. Nilai ini menunjukkan pemahaman responden bahwa menyatakan setuju bahwa motivasi siswa memiliki pengaruh terhadap proses imitasi yang ditunjukkan melalui proses peniruan di dalam kelas. Dalam praktik di kelas, melalui observasi siswa-siswi SD ZION bukan hanya menjadi pendengar saja di dalam kelas, tetapi mampu untuk meniru setiap gerakan yang diberikan oleh gurunya dalam belajar termasuk imitasi dalam menggambar mengenai penciptaan Tuhan dan siswa dapat menggambarnya kembali dengan bagus dan menarik. Tidak hanya itu saja, siswa mampu menjelaskan kembali apa yang telah ia pelajari selama pelajaran berlangsung, mengerjakan tugasnya secara mandiri.

\section{Hubungan Motivasi Terhadap Manipulasi}

Siswa memiliki pemahaman yang baik bahwa motivasi mereka untuk menggunakan konsep yang diajarkan oleh guru dapat mencapai 80,29\%. Artinya siswa-siswi mau melakukan apa yang disampaikan guru dan melakukannya dalam proses pembelajaran. Siswa-siswi SD ZION dapat meneladani firman Tuhan yang diajarkan oleh guru jika guru menjelaskan mengenai tokoh-tokoh yang diberkati oleh Tuhan dalam Alkitab dan mau melakukannya dalam kehidupannya sehari-hari. Siswa juga senang bila mendapatkan tugas dari gurunya supaya melatih diri mereka mengerjakan tugasnya dengan mandiri, selain itu jika ada hal-hal baru seperti lagu baru yang memakai gerakan mereka cepat untuk meniru, mengerjakan tugas kelompok dan bekerjasama dalam kelompok.

Namun demikian, belum sepenuhnya siswa mampu menampilkan hasil tugasnya di depan teman-teman sekelas di mana persentase menunjukkan bahwa responden lebih banyak memilih ragu-ragu menampilkan hasil tugasnya masing-masing. Hal ini disebabkan oleh guru belum melatih siswa untuk berani tampil di teman-teman sebayanya. Siswa secara berkelompok mampu menampilkan hasil kelompoknya secara bersama-sama.

Konsep yang digunakan dalam belajar bagi anak didik seharusnya konsep yang harus sesuai dengan etika dan moral. Penggunaan konsep yang sesuai dengan etika dan moral akan menghasilkan anak yang tidak sekadar berprestasi, melainkan anak yang berkarakter baik yang dapat menjadi contoh atau teladan bagi orang-orang di sekitarnya.

\section{Hubungan Motivasi Terhadap Presisi}

Hasil responden mengenai hubungan motivasi terhadap presisi menunjukkan persentase skala rating $83,42 \%$. Siswa-siswi SD ZION sangat senang memainkan drama dengan teliti tentang kisah tokoh-tokoh yang terjadi dalam Alkitab supaya mereka dapat mengerti dan mengaplikasikannya terhadap sesama. Siswa memiliki ketaatan kepada 
guru, dan ketelitian dalam belajar untuk mendapatkan nilai yang terbaik dan tidak memiliki keinginan untuk menyontek saat ulangan, berpikir tentang setiap tindakan yang dilakukan apakah sudah benar dengan aturan dan yang diajarkan guru sehingga sikap mereka dapat menjadi contoh bagi teman-teman yang masih salah dalam tindakan atau sikapnya.

Siswa dapat berinteraksi dengan teman sebayanya dan teliti dalam bergaul sehingga mereka dapat terhindar dari pengaruh pergaulan yang negatif. Namun masih ada siswa yang memliki keraguan dalam menyampaikan atau menjelaskan jawaban hasil tugasnya di depan temanteman dalam kelas. Siswa senang dengan sesuatu yang membuat mereka dapat meningkatkan kemampuan psikomotoriknya dan menjadi siswa yang aktif dalam belajar.

\section{Hubungan Motivasi Terhadap Artikulasi}

Siswa-siswi sudah memahami ajaran pendidikan Agama Kristen dan sudah dengan baik melakukan apa yang guru sampaikan untuk mereka lakukan dalam kehidupan sehari-hari termasuk dalam proses pembelajaran. Siswa-siswi SD ZION menghormati dan menghargai gurunya misalnya setiap bertemu guru maka mereka memberi sapa atau salam, ada keinginan dan tindakan untuk menolong orang lain yang membutuhkan. Di sekolah, dalam kelas sebelum pelajaran dimulai peserta didik duduk dengan tenang dan tidak menganggu temannya, bahkan mereka belajar membuang sampah pada tempatnya supaya lingkungan sekolah terlihat bersih. Tindakan siswa untuk berkompetisi dengan teman sebaya masih rendah karena masa perkembangan mereka adalah belajar dan bermain dalam kelompok. Oleh sebab itu, siswa SD Zion kelas V masih ada yang belum dapat tampil di hadapan teman sebayanya secara individu.

\section{Hubungan Motivasi Terhadap Naturalisasi}

Pada tahap naturalisasi siswa diharapkan untuk bertanggung jawab tentang apa yang mereka pahami dan lakukan. Siswa-siswi SD ZION mampu membedakan antara baik dan buruknya suatu sikap dan tindakan sehingga sikap yang baik, rajin dalam belajar dapat emengaruhi hasil belajar di sekolah. Pada tahap ini siswa melatih terus-menerus kemampuannya baik kognitif, afektif dan psikomotoriknya hingga menjadi alamiah dan memberi penguatan pada motivasi siswa untuk mendapatkan hasil belajar yang baik.

\section{Kesimpulan}

Hasil penelitian penulis secara keseluruhan tentang pentingnya motivasi ekstrinsik terhadap hasil belajar psikomotorik di SD Zion 
Makassar. Keterkaitan hasil belajar psikomotorik dipengaruhi oleh motivasi ekstrinsik adalah tinggi. Anak didik tidak hanya diajar untuk dapat memahami dan mengerti setiap pelajaran yang ada, tetapi didorong untuk bertanggung jawab dan menunjukkan kemampuan psikomotorik yang ada pada diri setiap peserta didik. Bagian penting dalam proses pendidikan seperti imitasi, artikulasi, presisi, manipulasi, naturalisasi merupakan hasil dari adanya metode belajar, proses belajar yang memadai, dan dari adanya motivasi yang tepat sesuai dengan kapasitas diri yang dimiliki oleh setiap anak didik. Setiap peserta didik juga mampu untuk menjadi teladan, panutan, dan contoh yang layak bagi orang lain melalui kehidupannya.

Pengaruh indikator motivasi ekstrinsik seperti hadiah, dan nilai memiliki pengaruh signifikan bagi siswa untuk meningkatkan hasil belajarnya. Sementara untuk indikator siswa termotivasi karena kompetisi tidak memberikan pengaruh yang nyata terhadap hasil belajar psikomotorik siswa.

Guru merupakan tokoh penting yang harus melaksanakan tanggung jawab dengan baik, tidak hanya menjadi pengajar dan pendidik tetapi juga bertanggung jawab menjadi motivator yang harus mendukung anak didik untuk terus belajar dan berupaya meningkatkan hasil psikomotorik belajar yang sebenarnya dapat terus berkembang ke arah yang lebih baik.

\section{Kepustakaan}

Arikunto, Suharsimi. Dasar-Dasar Evaluasi Pendidikan. Jakarta: Bumi Aksara, 2009.

Djamarah, Syaiful Bahri. Guru dan Anak Didik Dalam Interaksi Edukatif Jakarta: Rineka Cipta, 2000.

Djamarah, Syaiful Bahri. Psikologi Belajar. Jakarta: Rineka Cipta, 2008.

H., Dave R. Psychomotor Levels in Developing and Writing Behavorial Objectives. Arizona: Educational Innovators Press, 1970.

Hamdu, G., Lisa Agustina."Pengaruh Motivasi Belajar Siswa Terhadap

Prestasi Belajar IPA di Sekolah Dasar." Jurnal Penelitian Pendidikan 12,

No.l (April 2011):81-86.

Haryadi, T., Aripin. "Melatih Kecerdasan Kognitif, Afektif, dan

Psikomotorik Anak Sekolah Dasar Melalui Perancangan Game Simulasi "Warungku." Jurnal Desain Komunikasi Visual \& Multimedia l, No. 2 Tahun 2015:39-50.

Hasan Basri, Kapita Selekta Pendidikan. Bandung: Pustaka Setia, 2012.

Lestari, Nana C., Akhmad Riyadi. "Peningkatan Hasil Belajar Kognitif Siswa Kelas X-2 SMAN 1 Muara Pada Materi IPA Konsep Ekosistem 
Menggunakan Model Pembelajaran Kooperatif Tipe NHT." Cendekia 9, No. 2 (Oktober 2015): 166-171.

Muhibbin Syah, Psikologi Pendidikan dengan Pendekatan Baru. Bandung: Remaja Rosdakarya, 2008.

Mustaqim, Abdul Wahid. Psikologi Pendidikan. Jakarta: Rineka Cipta, 2013. Nurwati, Andi. "Penilaian Ranah Psikomotorik Siswa Dalam Pelajaran Bahasa." Edukasia: Jurnal Penelitian Pendidikan Islam 9, No. 2 (Agustus 2014):385-400.

Seifert, Kelvin. Manajemen Pembelajaran dan Instruksi Pendidikan (Jogjakarta: IRCiSoD, 2007.

Soemanto, Wasty. Psikologi Pendidikan:Landasan Kerja Pemimpin Pendidikan. Jakarta: Rineka Cipta, 2006.

Sudjana, Nana. Penilaian Hasil Proses Belajar Mengajar. Bandung: Remaja Rosdakarya, 2010.

Suryadi. Psikologi Belajar PAUD. Yogyakarta: Pustaka Insan Madani, 2010. Syarif, Izuddin. "Pengaruh Model Blended Learning Terhadap Motivasi dan Prestasi Belajar Siswa SMK." Jurnal Pendidikan Vokasi 2,No. 2 (Juni 2012):234-249.

Wahab, Rohmalina. Psikologi Belajar. Jakarta: RajaGrafindo Persada, 2016. 